\title{
Assessment of Arsenic Contamination in Deep Groundwater Resources of the Kathmandu Valley, Nepal
}

\author{
Suman Man Shrestha', Kedar Rijal', Megh Raj Pokhrel² \\ ${ }^{1}$ Central Department of Environmental Science, Tribhuvan University, Kirtipur, Kathmandu, Nepal \\ ${ }^{2}$ Central Department of Chemistry, Tribhuvan University, Kirtipur, Kathmandu, Nepal \\ Email: sshrestha@cdes.edu.np
}

Received November 2015

\begin{abstract}
This study was carried out to assess arsenic in deep groundwater resources in the Kathmandu Valley, Nepal and to predict arsenic mobilization process in relation to iron, manganese, $\mathrm{pH}$ and ORP. Forty-one deep groundwater samples were collected during pre monsoon and post monsoon in 2013. The depths of the wells were ranged from 84 to $304 \mathrm{~m}$. In pre monsoon and post monsoon, arsenic concentration in $17 \%$ and $26 \%$ of examined groundwater wells, respectively exceeded permissible World Health Organization (WHO) guideline value of $0.010 \mathrm{mg} / \mathrm{L}$ for drinking water. The concentrations of arsenic were in the range between $<0.003$ to $0.137 \mathrm{mg} / \mathrm{L}$. The study demonstrated elevated concentrations of iron and manganese in the groundwater. Arsenic is highly correlated with iron and manganese. The strong negative correlation between arsenic and ORP indicates that arsenic mobilization occurs under reducing condition. These distinct relationships indicate that arsenic release is considered to be affected by the reductive dissolution of $\mathrm{Fe} / \mathrm{Mn}$ oxides in the groundwater. Arsenic has very weak negative correlation with $\mathrm{pH}$ suggesting less effect of $\mathrm{pH}$ on arsenic mobilization. Arsenic is not significantly correlated with the season which infers similar distribution of arsenic in both seasons. Arsenic varies spatially in groundwater of the valley showing high concentrations in central groundwater district.
\end{abstract}

\section{Keywords}

Arsenic, Deep Groundwater, Reductive Dissolution, Kathmandu Valley

\section{Introduction}

Heavy metal contamination of groundwater is one of the major problems in the world. The heavy metals that occur as natural contaminants of groundwater and are potentially bio-hazardous include manganese (Mn), lead $(\mathrm{Pb})$, cadmium (Cd), mercury (Hg) and arsenic (As) [1] [2]. Arsenic is recognized as a toxic element and has been classified as a human carcinogen affecting skin and lungs [3]. Arsenic has strong toxicity at even low concentrations and can accumulate in body tissues over long periods of time and is nonessential for human health [4] [5]. So, elevated levels of arsenic constitute problems for water supplies around the world [6]. In recent past

How to cite this paper: Shrestha, S.M., Rijal, K. and Pokhrel, M.R. (2015) Assessment of Arsenic Contamination in Deep Groundwater Resources of the Kathmandu Valley, Nepal. Journal of Geoscience and Environment Protection, 3, 79-89. 
years, the occurrence of high concentrations of arsenic has been detected in groundwater from a number of regions across the world. The problem has increased greatly in recent years in several regions of Southeast Asia. In this region, countries affected with arsenic in groundwater include Bangladesh, several states of India (West Bengal, Bihar, Uttar Pradesh, Jharkhand, Assam, Chhattisgarh and Manipur), Nepal, Myanmar, Pakistan, Vietnam, Lao People's Democratic Republic, Cambodia and China [7] [8].

The demand for water is increasing due to rapid growth of urban population and industrial activities in the Kathmandu Valley. There is a high decadal population growth rate found in Kathmandu district i.e., 61.23\% [9]. As a result there is an immense pressure on groundwater resources in the valley. Groundwater was first exploited for water supply in 1970 in the valley. Mechanized extraction of groundwater resources began in 1984. Groundwater is an important water resource in the Kathmandu Valley. It contributes about $50 \%$ of the total water supply in the valley [10]. In dry season, $60 \%$ to $70 \%$ of the water supply is met by ground water [11].

There have been several studies of assessment of arsenic in groundwater of the Kathmandu Valley. Groundwater survey of the valley reported the presence of arsenic and the concentrations were below WHO (1993) guideline values [12]. Similar study revealed that the ground water resource in the valley is contaminated with arsenic in deep aquifers [13]. Likewise, other studies have reported elevated levels of arsenic in groundwater of the valley [14]-[19]. Arsenic in groundwater wells in the Kathmandu Valley is one of the major environmental issues due to its negative health impact and more than $50 \%$ of water supply in the valley is derived from groundwater resources. So, this paper presents an overall study on the occurrence, mobilization and distribution of arsenic in deep groundwater resources in the valley. The study attempted to visualize spatial distribution pattern of arsenic in northern groundwater district (NGWD), central groundwater district (CGWD) and southern groundwater district (SGWD) in the valley in GIS environment. The study also aimed to demonstrate temporal (seasonal) variation of arsenic. The possible relationship between arsenic and depth of the groundwater was also examined.

\section{Materials and Methods}

\subsection{Study Area}

The Kathmandu Valley is in the hilly region of Nepal. It is roughly circular with diameter of $25 \mathrm{~km}$ and an average altitude of $1300 \mathrm{~m}$ (above sea level) located in the central Nepal Himalaya, lies in between $27^{\circ} 32^{\prime}$ and $27^{\circ} 49^{\prime}$ North and $85^{\circ} 12^{\prime}$ and $85^{\circ} 32^{\prime}$ East (Figure 1). Its surrounding hills are approximately $2800 \mathrm{~m}$ (above sea

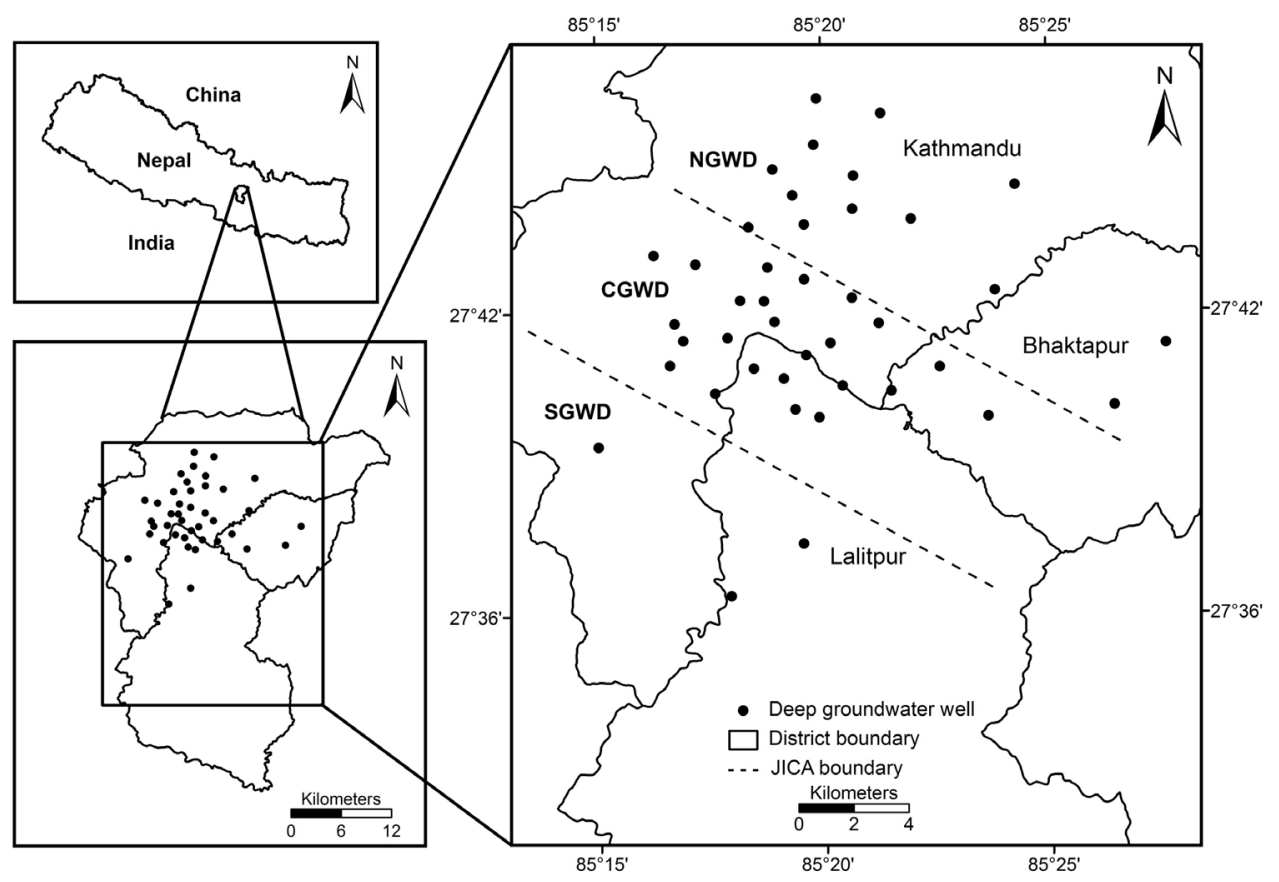

Figure 1. Location map of study area in Kathmandu Valley, Nepal and sampling locations. 
level). The area of the Kathmandu Valley is about $650 \mathrm{~km}^{2}$. The valley comprises of three major cities: Kathmandu, Lalitpur and Bhaktapur. The capital city Kathmandu is the largest city of Nepal. The annual rainfall of the Kathmandu Valley is $1465 \mathrm{~mm}$ [20]. The valley receives $80 \%$ of annual rainfall during monsoon (JuneSeptember) [10].

The Kathmandu Valley is an intermontane basin overlying the bedrock formations up to $500 \mathrm{~m}$ of a thick band of Pliocene-quaternary fluvio-lacustrine unconsolidated sediments [21]. The valley sediment is referred as Kathmandu Complex and is composed of Paleozoic and Precambrian-age rocks. The limestone dominates to the south, whereas to the east and west, the valley is bordered by phyllites and siltstones. Granite gneisses thrust into the rocks of the Kathmandu Complex that form the northern border of the valley [22].

Based on hydrochemical and hydrogeological conditions, JICA [23] divided the deep aquifer of the Kathmandu Valley into three groundwater districts: northern, central and southern. The northern groundwater district is considered as main aquifer and has greater abilities to recharge the groundwater. The upper deposits of the district composed of unconsolidated and highly permeable micaceous quartz, sand and gravel of about $60 \mathrm{~m}$ thick, interbedded with several impermeable fine layers. In the central groundwater district, the upper deposits are overlaid by impermeable very thick stiff black clay with peat and lignite bands, named as Kalimati Formation. The Kalimati Formation is covered by fluvial deposits of fine to medium sand and silt intercalated with clay and fine gravels. The widespread presence of black clay layer is the barrier in groundwater recharge in the central groundwater district. The urban cores of Kathmandu and Lalitpur are located in this central groundwater district. The southern groundwater district is characterized by a thick impermeable clay and basal gravel of low permeability. But some parts of the eastern area of southern groundwater district have potential for groundwater recharge due to presence of sand and gravel deposits [23]-[25].

\subsection{Water Sampling and Analysis}

The study was carried out in 41 deep groundwater wells ( $>60 \mathrm{~m}$ ) during pre monsoon and post monsoon seasons in 2013 (Figure 1). The study covered the groundwater wells of 84 to $304 \mathrm{~m}$ depth. The geo-positions of groundwater sampling locations were determined using global positioning system (GPS). Random sampling technique was used to collect groundwater samples. The locations of all the samples were recorded by handheld Garmin-E GPS and referenced to WGS 84 coordinate system. The high density polyethylene (HDPE) sampling bottles were treated with $5 \% \mathrm{HNO}_{3}$ and then rinsed with double distilled water. Samples from wells were collected by using 500-mL Nalgene (UK) HDPE bottles. A set of samples were collected in sampling bottles after pumping water for five minutes to get the representative samples of groundwater wells. The bottles were labeled with the sample code number. These samples were preserved as per APHA-AWWA-WEF (2005) [26] and then brought to the laboratory for the analysis. The samples were kept at $4{ }^{\circ} \mathrm{C}$ prior to analysis. Oxidation reduction potential (ORP), electrical conductivity (EC), $\mathrm{pH}$ and temperature were measured in situ at each sampling locations. The ORP and $\mathrm{pH}$ were measured by Hanna HI 8314 pH/ORP meter (Italy). The EC was measured by Jenway 4200 conductivity meter (UK).

The analysis of total arsenic, total iron and total manganese were carried out in Nepal standard (NS) certifiedCEMAT Water Laboratory by using Varian AA 240 atomic absorption spectrometer (AAS). The analysis of arsenic was carried out using Varian AA 240 atomic absorption spectrometer (Australia) with vapor generation accessory VGA-77 (Australia). The standard solutions produced by Merck, Germany traceable to standard reference material (SRM) of NIST (National Institute of Standards and Technology, Gaithersburg, MD, USA) were used to prepare calibration standards. The samples for the analysis of arsenic, iron and manganese were digested with high purity $\mathrm{HNO}_{3}$ (Merck) within a week of sample collection as per APHA-AWWA-WEF (2005). Sample digestion with the $\mathrm{HNO}_{3}$ allows total extraction of the metals from the samples. Three replications of each analysis were performed and mean values were used for calculations. Analytical reagent blanks were prepared for each batch of the digestion set and then analyzed for the same elements as the samples. Analytical precision was in good agreement, generally better than 5\% RSD. SPSS version 18 was used for all statistical analyses.

Nepal adopted universal transverse mercator (UTM) projection for the base mapping of the country with some modifications suited to its shape. This is named as modified universal transverse mercator projection. So, all the spatial data layers were maintained in a standard Nepalese coordinate system of modified universal transverse mercator, central meridian $84^{\circ}$ longitude (i.e., MUTM 84). The software used for mapping and spatial analysis was ArcGIS version 9.3. 


\section{Results and Discussion}

\subsection{Physicochemical Parameters and Metals}

The summary of values of $\mathrm{pH}, \mathrm{EC}$, ORP and the concentrations of metals in the groundwater wells are presented in Table 1. The $\mathrm{pH}$ were nearly neutral that ranged from 6.4 to 7.9 (mean $=6.8$ ) and 6.3 to 7.9 (mean = 6.7) in pre monsoon and post monsoon, respectively. The EC ranged from 92 to $1715 \mu \mathrm{S} / \mathrm{cm}$ (mean $=567 \mu \mathrm{S} / \mathrm{cm}$ ), 93 to $1666 \mu \mathrm{S} / \mathrm{cm}$ (mean $=565 \mu \mathrm{S} / \mathrm{cm}$ ) in pre monsoon and post monsoon, respectively. The elevated EC value is mainly due to geological sources since groundwater contamination is less in deep aquifers due to presence of widespread thick lacustrine clay beds that significantly restrict downward percolation [27] and leaching of ions contributing conductivity would be limited.

The mean values for ORP in the groundwater wells were $-59 \mathrm{mV}$ in pre monsoon and $-49 \mathrm{mV}$ in post monsoon. The negative ORP value was up to $-161 \mathrm{mV}$ indicates that the groundwater wells are under reducing condition. A study reported negative ORP value up to $-195 \mathrm{mV}$ in deep groundwater [14]. Likewise, another study indicated low ORP value in deep groundwater with mean value of $-82 \mathrm{mV}$ in pre monsoon and $-56 \mathrm{mV}$ in monsoon [17]. The groundwater wells in the study area are relatively anoxic, as indicated by low ORP values. The dominance of thick lacustrine clay probably restricts the downward diffusion of oxidants such as oxygen in deep groundwater [28].

The mean iron concentration in deep groundwater wells were $3.61 \mathrm{mg} / \mathrm{L}$ in pre monsoon and $3.76 \mathrm{mg} / \mathrm{L}$ in post monsoon with the highest concentration of $12.99 \mathrm{mg} / \mathrm{L}$ in post monsoon. Iron oxides dissolve under strongly acidic and reducing environment. If present in water in excessive amounts, it forms red Fe oxyhydroxide. Reductive dissolution of Fe(III) oxides accounts for the high Fe(II) content in anaerobic water [29] [30]. The chemical composition of the major elements of the sediments, i.e., $\mathrm{Fe}_{2} \mathrm{O}_{3}$ ranged from 1.48 to $9.55 \mathrm{wt} \%$ [31] could be the source of iron in groundwater of the valley. A similar study indicated the $\mathrm{Fe}_{2} \mathrm{O}_{3}$ contents of the sediments are generally high (ranges $<0.5$ to $15 \mathrm{wt} \%$ ), and are uniformly higher in the fine sediments of the central basin (average $7 \mathrm{wt} \%$ ) [28]. The overall bulk elemental concentrations in the central basin are greater in comparison with the northern part. The total iron content in the black sticky clay is high (> $7 \mathrm{wt} \%)$ [32]. The variation in $\mathrm{Fe}_{2} \mathrm{O}_{3} \%$ and redox state of groundwater might have affected the levels of iron concentration in the groundwater.

Manganese concentration ranged from $<0.02$ to $1.55 \mathrm{mg} / \mathrm{L}$ (mean $=0.44 \mathrm{mg} / \mathrm{L}$ ) in pre monsoon, whereas $<0.02$ to $1.75 \mathrm{mg} / \mathrm{L}$ (mean $=0.42 \mathrm{mg} / \mathrm{L}$ ) in post monsoon. The chemical composition of the major element of the sediments, i.e., $\mathrm{MnO}$ from 0.01 to $0.18 \mathrm{wt} \%$ [31] is probable source of manganese in the groundwater of the valley. In the study area, arsenic concentration in the groundwater wells ranged from $<0.003$ to $0.137 \mathrm{mg} / \mathrm{L}$ (mean $=0.013 \mathrm{mg} / \mathrm{L}$ ) in pre monsoon and $<0.003$ to $0.131 \mathrm{mg} / \mathrm{L}$ (mean $=0.011 \mathrm{mg} / \mathrm{L}$ ) in post monsoon. Arsenic concentration in $17 \%$ in pre monsoon and $26 \%$ in post monsoon exceeded provisional World Health Organization guideline value for drinking water of $0.010 \mathrm{mg} / \mathrm{L}$ [33]. A similar study reported arsenic concentration up to $0.265 \mathrm{mg} / \mathrm{L}$ [13]. Iron oxyhydroxides are the common host matter for arsenic, either adsorbed into the surface or co-precipitated [34] and reductive process is responsible for arsenic mobilization by dissolution or desorption in the groundwater [35]-[39], so it is possible that the higher concentration of arsenic in the groundwater is due to the more reducing environment as indicated by lower ORP value. Likewise, under the aerobic and acidic to near neutral conditions typical of many natural environments, arsenic is strongly adsorbed by oxide minerals as the arsenate ion and the concentrations in solution are low [40].

Table 1. Summary of statistical data for physicochemical parameters and metals.

\begin{tabular}{|c|c|c|c|c|c|c|c|c|c|c|c|}
\hline \multirow{2}{*}{ Variable } & \multirow{2}{*}{ Unit } & \multicolumn{5}{|c|}{ Pre monsoon } & \multicolumn{5}{|c|}{ Post monsoon } \\
\hline & & Min. & Max. & Mean & Med. & SD & Min. & Max. & Mean & Med. & SD \\
\hline Depth & M & 84 & 304 & 222.0 & 247 & 63.4 & 84 & 304 & 222.0 & 247 & 63.4 \\
\hline $\mathrm{pH}$ & & 6.4 & 7.9 & 6.8 & 6.7 & 0.4 & 6.3 & 7.9 & 6.7 & 6.6 & 0.4 \\
\hline EC & $\mu \mathrm{S} / \mathrm{cm}$ & 92 & 1715 & 567 & 452 & 381 & 93 & 1666 & 565 & 456 & 379 \\
\hline ORP & $\mathrm{mV}$ & -161 & 134 & -59 & -76 & 68 & -120 & 135 & -49 & -56 & 55 \\
\hline $\mathrm{Fe}$ & $\mathrm{mg} / \mathrm{L}$ & BDL & 11.09 & 3.61 & 2.88 & 2.88 & 0.10 & 12.99 & 3.76 & 2.79 & 2.87 \\
\hline Mn & mg/L & BDL & 1.55 & 0.44 & 0.37 & 0.35 & BDL & 1.75 & 0.42 & 0.31 & 0.4 \\
\hline As & $\mathrm{mg} / \mathrm{L}$ & BDL & 0.137 & 0.011 & 0.003 & 0.024 & BDL & 0.131 & 0.013 & 0.005 & 0.023 \\
\hline
\end{tabular}

Min. = Minimum, Max. = Maximum, Med. = Median, SD = Standard deviation, BDL = Below detection limit. 
The groundwater wells observed elevated concentrations of iron and manganese. It is observed that the concentrations of iron and manganese are $\mathrm{pH}$ dependent and higher aggressiveness of iron and manganese in low $\mathrm{pH}$ [41]. Likewise, it is suggested that presence of a reductant (such as organic carbon) is a dominant factor controlling iron and manganese concentrations in groundwater. The oxidation of the reductant would leads to the reduction and solubilisation of iron and manganese [42] and the lacustrine clay in the Kathmandu Valley is rich is organic matter [43] would contribute to the reducing environment. The organic matter may play an important role in the mobilization of arsenic, as reported by many studies from West Bengal (India) and Bangladesh [35] [44] [45]. It has been indicated that the fluvio-lacustrine sediments in the valley are rich in organic matter, and this organic matter may contribute in mobilization of arsenic.

\subsection{Correlation between Physicochemical Parameters and Arsenic}

The relationships of $\mathrm{pH}, \mathrm{EC}$, ORP and metals in the groundwater were examined by Spearman's rank correlation coefficient (Table 2). The $\mathrm{pH}$ has strong negative correlations with iron and manganese, and weak negative correlation with arsenic $(\mathrm{r}=-0.534, p<0.01 ; \mathrm{r}=-0.402, p<0.01 ; \mathrm{r}=-0.169, p<0.129)$ which can be explained by the higher aggressiveness of acidic media towards soil and host rocks that increase the concentrations of the rest of the ions [41]. Though arsenic has negative correlation, $p$-value suggests that there is an insignificant negative correlation between arsenic concentration and $\mathrm{pH}$ in the groundwater. The EC shows strong positive correlations (at $p<0.01$ ) with iron, manganese and arsenic. Arsenic has strong positive correlations with iron and manganese $(\mathrm{r}=0.384, p<0.01 ; \mathrm{r}=0.447, p<0.01)$, which is attributed to common geogenic origin of these metals. The ORP has strong negative correlation with arsenic $(\mathrm{r}=-0.492, p<0.01)$, which can be explained by reductive arsenic mobilization mechanisms in the groundwater. Likewise, ORP also shows negative correlations with iron and manganese. Reducing environment is responsible for the release of iron as well as manganese through the reduction of Mn(III, IV) (hydr)oxides to soluble Mn(II) and of Fe(III) (hydr)oxides to soluble Fe(II), respectively.

Table 2. Spearman's rank correlation coefficients of physicochemical parameters and metals $(\mathrm{n}=82)$.

\begin{tabular}{|c|c|c|c|c|c|c|}
\hline Parameter & $\mathrm{pH}$ & EC & ORP & $\mathrm{Fe}$ & $\mathrm{Mn}$ & As \\
\hline $\mathrm{pH}$ & 1.000 & & & & & \\
\hline EC & $-0.332^{* *}$ & 1.000 & & & & \\
\hline ORP & 0.052 & $-0.664^{* *}$ & 1.000 & & & \\
\hline $\mathrm{Fe}$ & $-0.534^{* *}$ & $0.591^{* *}$ & $-0.570^{* * *}$ & 1.000 & & \\
\hline Mn & $-0.402^{* *}$ & $0.654^{* *}$ & $-0.447^{* *}$ & $0.656^{* *}$ & 1.000 & \\
\hline As & -0.169 & $0.463^{* *}$ & $-0.492^{* *}$ & $0.384^{* *}$ & $0.447^{* *}$ & 1.000 \\
\hline
\end{tabular}

\footnotetext{
${ }^{* *}$ Significant value at $p<0.01$.
}

\subsection{Correlation between Arsenic and Depth of Groundwater}

The depth of the deep groundwater wells tested arsenic ranged from 84 to $304 \mathrm{~m}$. The mean and standard deviation (SD) of depth were $222.0 \mathrm{~m}$ and $63.4 \mathrm{~m}$ respectively (Table 1). The study showed weak positive correlations between arsenic and depth of groundwater in pre monsoon and post monsoon $(\mathrm{r}=0.206, p=0.196 ; \mathrm{r}=$ $0.178, p=0.266$ ), respectively. Though, it showed positive correlations in both seasons, $p$-values suggest that there are insignificant positive correlations between arsenic concentration and depth of groundwater. However, it contradicts with the results shown by the some previous studies [13] [15].

\subsection{Temporal (Seasonal) Variation of Arsenic}

The temporal (seasonal) variation of the physicochemical parameters and metals were evaluated through season-parameter Spearman's correlation matrix in the groundwater. The measured parameters are not significantly $(p>0.05)$ correlated with the season except for $\mathrm{pH}(\mathrm{r}=-0.238, p<0.05)$, which infers similar distribution of arsenic in both seasons. Arsenic concentrations were insignificantly varied between seasonal groundwater. A study also reported very similar distributions of arsenic for pre monsoon and monsoon [15]. 
The lack of temporal (seasonal) variation is attributed to less dilution effect of monsoon rainfall in the groundwater. Additionally, contribution of anthropogenic metal contaminations is reluctant in the studied timeseries in the groundwater wells. These findings are consistent with the results of previous study which pointed out seasonal variability has no significant effect on deep groundwater quality [17]. The similar studies also indicated no seasonal variability of arsenic in the groundwater [15] [16]. The reports on the temporal variation of arsenic concentration in other parts of the world are inconsistent. Significant variation in arsenic concentration among the seasons was observed in a study [46]. A study spotted no significant monsoonal effects on arsenic distribution [47]. The seasonal variability has little effect in the groundwater [48]. Likewise, limited temporal variability observed in arsenic concentrations in groundwater [49] [50].

\subsection{Spatial Distribution of Arsenic}

The concentration of arsenic, iron, manganese and ORP value vary significantly in central, northern and southern groundwater districts in the valley (Figures 2(a)-(d)). The spatial distribution pattern reveals higher values of arsenic, iron and manganese in central groundwater district. Northern and southern groundwater districts have lower arsenic concentrations in most of the groundwater wells. The concentration of the arsenic in groundwater of the study area increases from northern to southern and showing highest towards central groundwater district. Arsenic concentration was relatively lower in southern groundwater district in comparison with central groundwater district. The spatial distribution of ORP in the groundwater clearly shows most of the groundwater wells have lower ORP value.

The variations of elemental concentration are mainly clay controlled in both the margin and central parts. There is progressive increase in the finer particles and trace elements towards the central part of the sediments from the northern part in the valley [32] which is attributed to decrease in grain size and the concentration of metals in sediments tend to increase in fine grained sediments [32] [51] [52]. The larger particles in sediments have less surface area available for metal hydroxide coatings to form and adsorb arsenic and less adsorbed arsenic contributes a smaller amount of aqueous arsenic in equilibrium with adsorbed arsenic. Therefore, there is in less potential for release of arsenic through reductive mobilization mechanisms [53]. The variation in grain size has role in mobilization of metals in groundwater. Therefore, higher metal concentration is associated with the fine grained sediments in the central groundwater district. Furthermore, higher concentrations of metals in central groundwater district might be due to the fact that the central groundwater district is considered as poorly recharging due to the presence of a thick black clay layer [23].

Groundwater quality depends on the composition of recharging water, the mineralogy and reactivity of the geological formations in aquifers, anthropogenic activities and environmental conditions that may affect the geochemical mobility of certain constituents [54]. Arsenic concentrations in groundwater of the Kathmandu Valley show a wide range and some of groundwater sources investigated were found to be in elevated levels in some parts of the valley could be due to the nature of the sediments there. The high degree of spatial variability in groundwater quality over short distances indicates that groundwater movement has been limited and is poorly mixed [55].

Arsenic concentrations in the sediments of the Kathmandu Valley averaged $8 \mathrm{mg} / \mathrm{kg}$ (ranging 3 to $25 \mathrm{mg} / \mathrm{kg}$ ) similar to the general level seen in modern unconsolidated sediments, typically 5 to $10 \mathrm{mg} / \mathrm{kg}$ [32] [36]. The widespread lacustrine clay of the Kathmandu Valley could have greater potentiality for arsenic release [32]. Arsenic mobilization is high in the reducing conditions [36] [56] [57]. The higher concentration of arsenic under reduced groundwater environment may be due to Fe/Mn oxides and direct reduction of $\mathrm{As}(\mathrm{V})$ into $\mathrm{As}(\mathrm{III})$. After an initial increase, arsenic concentration often decreases again as a function of time below water table due to sulfide precipitation, whereas it increases with increasing sulfate concentrations above water table [58]. Under moderately reduced environment $(0$ to $100 \mathrm{mV}$ ), arsenic solubility seemed to be controlled by the dissolution of Fe oxyhydroxides. But at highly reduced condition, e.g., at $-250 \mathrm{mV}$, arsenic chemistry is dominated by the formation of insoluble sulfides FeAsS, AsS, $\mathrm{As}_{2} \mathrm{~S}_{3}$ [56] attenuating concentration of arsenic in the groundwater.

\section{Conclusion}

This study has confirmed the presence of higher levels of arsenic in deep groundwater of the Kathmandu Valley. Arsenic showed wide spatial variation ranged from $<0.003$ to $0.137 \mathrm{mg} / \mathrm{L}$. In pre monsoon and post monsoon, $17 \%$ and $26 \%$ of groundwater wells, respectively exceeded arsenic concentration of permissible WHO guideline 


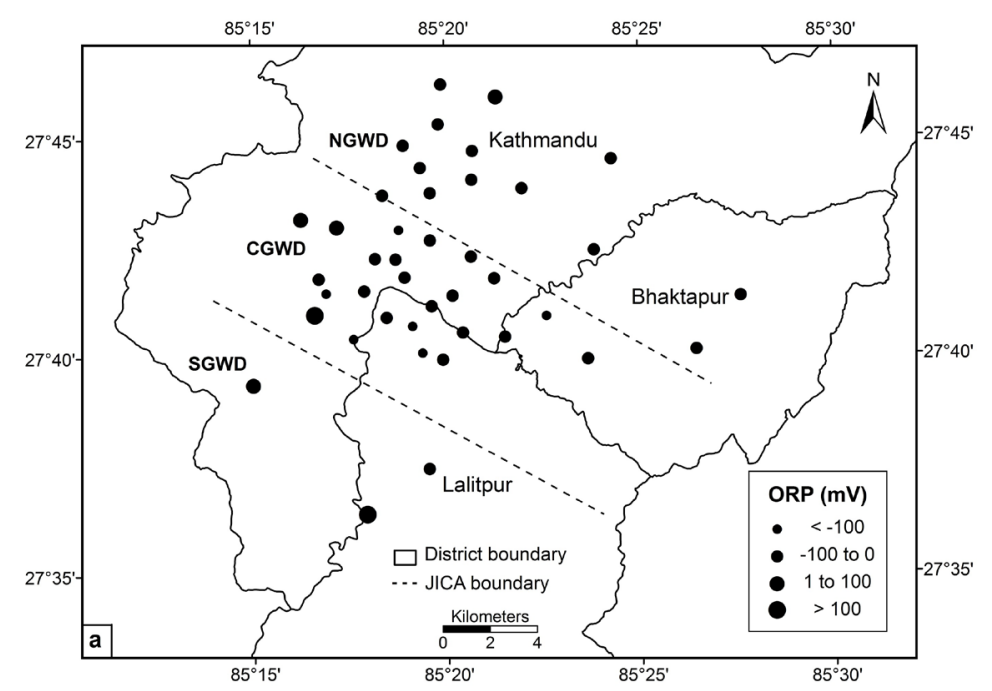

(a)

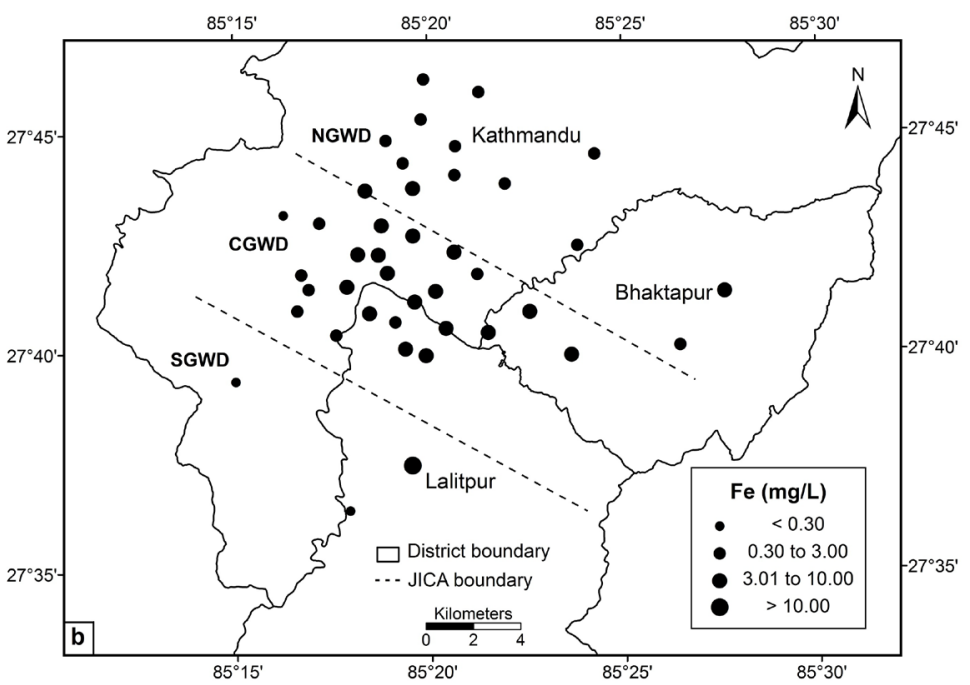

(b)

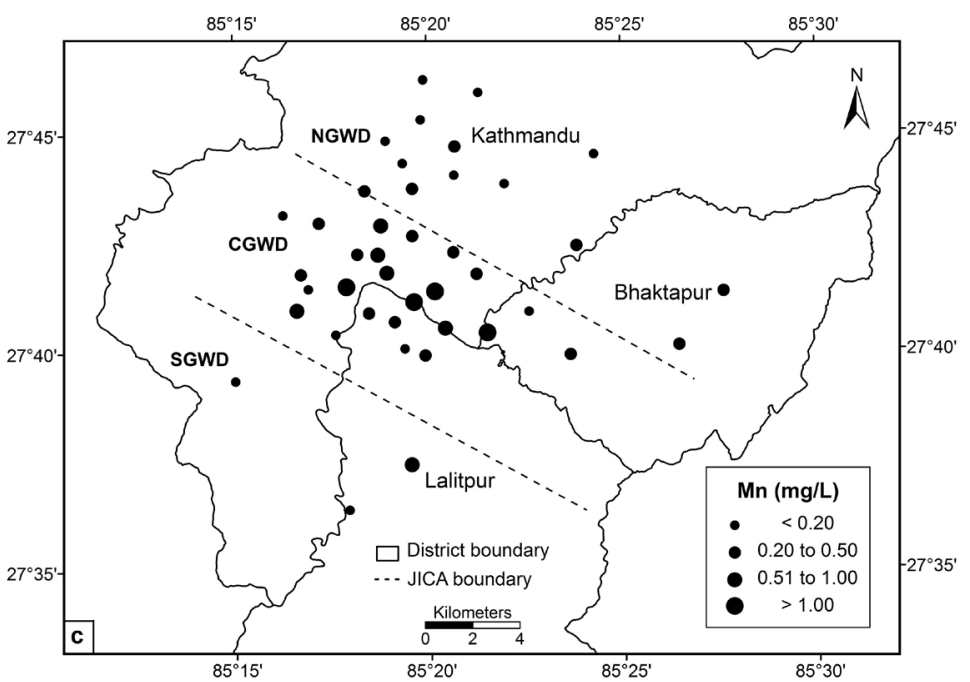

(c) 


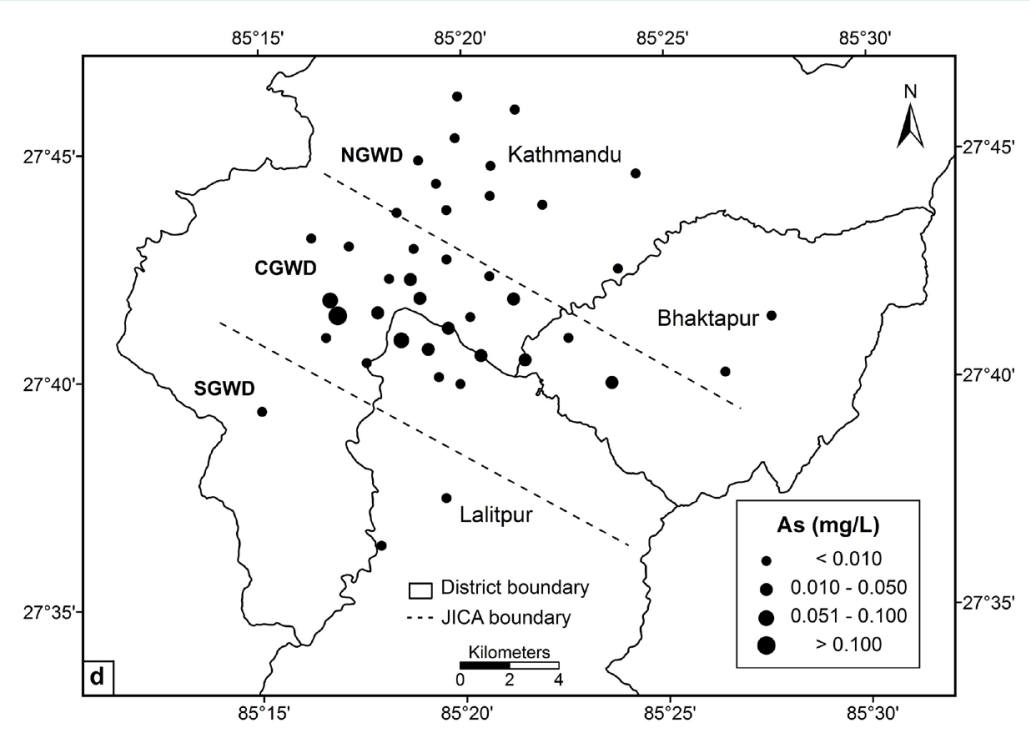

(d)

Figure 2. Spatial distribution: (a) ORP; (b) iron; (c) manganese and (d) arsenic.

value of $0.010 \mathrm{mg} / \mathrm{L}$ for drinking water. The arsenic varies spatially with high concentration towards central groundwater district. Strong negative correlation between arsenic and ORP demonstrated reductive arsenic mobilization mechanisms in deep groundwater. Arsenic showed strong correlations with iron, manganese and EC. Iron and manganese are presumably the main factors in regulating release of As in groundwater through reductive mobilization mechanism. The study revealed weak positive correlation between arsenic concentration and depth of deep groundwater. Arsenic is not significantly correlated with season suggesting similar distribution of arsenic in both seasons. The high concentration of arsenic in deep groundwater of some parts of study area particularly in central groundwater district is attributed to the groundwater geochemistry of the study area. Release of arsenic into the groundwater is considered to be due to the natural source under the reductive process.

\section{Acknowledgements}

The authors would highly acknowledge Central Department of Environmental Science, Tribhuvan University, Kirtipur, Kathmandu, Nepal for the support of this research work. We would like to thank University Grants Commission, Nepal for a research grant. Thanks also due to CEMAT Water Laboratory, Kathmandu, Nepal for providing laboratory facilities for the analysis of metals using atomic absorption spectrometer (AAS).

\section{References}

[1] Jarup, L. (2003) Hazards of Heavy Metal Contamination. British Medical Bulletin, 68, 167-182. http://dx.doi.org/10.1093/bmb/ldg032

[2] Mitchell, E., Frisbie, S. and Sarkar, B. (2011) Exposure to Multiple Metals from Groundwater-A Global Crisis: Geology, Climate Change, Health Effects, Testing and Mitigation. Metallomics, 3, 874-908. http://dx.doi.org/10.1039/c1mt00052g

[3] IARC (2004) IARC Monographs on the Evaluation of Carcinogenic Risks to Humans, Volume 84, Some Drinking-water Disinfectants and Contaminants, Including Arsenic. International Agency for Research on Cancer, Lyons.

[4] Garbarino, J.R., Hayes, H.C., Roth, D.A., Antweiler, R.C., Brinton, T.I. and Taylor, H.E. (1995) Heavy Metals in the Mississippi River. US Geological Survey Circular 1133, Virginia.

[5] Marcovecchio, J.E., Botte, S.E. and Freije, R.H. (2007) Heavy Metals, Major Metals, Trace Elements. In: Nollet, M.L., Ed., Handbook of Water Analysis. 2nd Edition, CRC Press, London, 275-311. http://dx.doi.org/10.1201/9781420006315.ch11

[6] Appelo, C.A.J. and Postma, D. (2005) Geochemistry, Groundwater and Pollution. 2nd Edition, A.A. Balkema Publishers, Amsterdam. http://dx.doi.org/10.1201/9781439833544

[7] Mukherjee, A., Sengupta, M.K., Hossain, M.A., Ahamed, S., Das, B., Nayak, B., Lodh, D., Rahman, M.M. and Cha- 
kraborti, D. (2006) Arsenic Contamination in Groundwater: A Global Perspective with Emphasis on the Asian Scenario. Journal of Health, Population and Nutrition, 24, 142-163.

[8] Hossain, M.F. (2006) Arsenic Contamination in Bangladesh-An Overview. Agriculture, Ecosystems and Environment, 113, 1-16. http://dx.doi.org/10.1016/j.agee.2005.08.034

[9] CBS (2012) National Population and Housing Census 2011. National Report. Volume 1, NPHC 2011. Nepal Bureau of Statistics, Kathmandu.

[10] Acres International (2004) Optimizing Water Use in Kathmandu Valley (ADB-TA) Project. Final Report. Acres International in Association with Arcadis Euroconsult Land and Water Product Management Group, East Consult (P) Ltd. and Water Asia (P) Ltd.

[11] ICIMOD (2007) Kathmandu Valley Environment Outlook. International Centre for Integrated Mountain Development, Kathmandu.

[12] Jha, M.G., Khadka, M.S., Shrestha, M.P., Regmi, S., Bauld, J. and Jacobson, G. (1997) The Assessment of Groundwater Pollution in Kathmandu, Nepal. Report on Joint Nepal-Australia Project, 1995-96. Australian Geological Survey Organization.

[13] JICA/ENPHO (2005) Arsenic Vulnerability in Groundwater Resources in Kathmandu Valley. Final Report. Japan International Cooperation Agency/Environment and Public Health Organization, Kathmandu.

[14] Khatiwada, N.R., Takizawa, S., Tran, T.V.N. and Inoue, M. (2002) Groundwater Contamination Assessment for Sustainable Water Supply in Kathmandu Valley, Nepal. Water Science Technology, 46, 147-154.

[15] Maharjan, M., Shrestha, B.R., Shrestha, K.B., Shrestha, R.R., Raut-Khadka, R., Shrestha, S.D., Kafle, B. and Ishihara, H. (2006) Arsenic Contamination in Groundwater Resources in Kathmandu Valley. 4th International Symposium on Southeast Asian Water Environment, Bangkok.

[16] Chapagain, S.K., Shrestha, S., Nakamura, T., Pandey, V.P. and Kazama, F. (2009) Arsenic Occurrence in Groundwater of Kathmandu Valley, Nepal. Desalination and Water Treatment, 4, 248-254. http://dx.doi.org/10.5004/dwt.2009.492

[17] Chapagain, S.K., Pandey, V.P., Shrestha, S., Nakamura, T. and Kazama, F. (2010) Assessment of Deep Groundwater Quality in Kathmandu Valley Using Multivariate Statistical Techniques. Water Air Soil Pollution, 210, 277-288. http://dx.doi.org/10.1007/s11270-009-0249-8

[18] Shrestha, S.M., Rijal, K. and Pokhrel, M.R. (2013) Arsenic Contamination in the Deep and Shallow Groundwater of Kathmandu Valley, Nepal. Scientific World, 10, 25-31. http://dx.doi.org/10.3126/sw.v11i11.8548

[19] Shrestha, S.M., Rijal, K. and Pokhrel, M.R. (2014) Spatial Distribution and Seasonal Variation of Arsenic in Groundwater of Kathmandu Valley, Nepal. Journal of Institute of Science and Technology, T.U., 19, 7-13.

[20] CBS (2013) Environment Statistics of Nepal. Nepal Bureau of Statistics, Kathmandu.

[21] Yoshida, M. and Igarashi, Y. (1984) Neogene to Quaternary Lacustrine Sediments in the Kathmandu Valley, Nepal. Journal of Nepal Geological Society, 4, 73-100.

[22] Shrestha, S.D., Karmacharya, R. and Rao, G.K. (1996) Estimation of Groundwater Resources in Kathmandu Valley, Nepal. Journal of Groundwater Hydrology, 38, 29-40. http://dx.doi.org/10.5917/jagh1987.38.29

[23] JICA (1990) Groundwater Management Project in the Kathmandu Valley. Final Report to Nepal Water Supply Corporation. Japan International Cooperation Agency, Kathmandu.

[24] Sakai, T., Gajurel, A.P., Tabata, H. and Uprety, B.N. (2001) Small Amplitude Lake-Level Fluctuations Recorded in Aggrading Deltaic of the Upper Pleistocene Thimi and Gokarna Formations, Kathmandu Valley, Nepal. Journal of Nepal Geological Society, 25, 43-52.

[25] Dixit, A. and Upadhya, M. (2005) Augmenting Groundwater in Kathmandu Valley: Challenges and Possibilities. Report to Nepal Water Conservation Foundation, Kathmandu, Nepal.

[26] APHA-AWWA-WEF (2005) Standard Methods for the Examination of Water and Wastewater. 21st Edition, American Public Health Association, American Water Works Association, Water Environment Federation, Washington DC.

[27] Pathak, D.R., Hiratsuka, A., Awata, I. and Chen, L. (2009) Groundwater Vulnerability Assessment in Shallow Aquifer of Kathmandu Valley Using GIS-Based Drastic Model. Environmental Geology, 57, 1569-1578. http://dx.doi.org/10.1007/s00254-008-1432-8

[28] Gurung, J.K. (2007) Geochemical Studies of Sediments and Water, and Implications for Mobilization of Arsenic into Groundwater in Nepal and Japan. Ph.D. Thesis, Shimane University, Japan.

[29] Hem, J.D. (1985) Study and Interpretation of Chemical Characteristics of Natural Water. 3rd Edition, US Geological Survey Water-Supply Paper 2254.

[30] Smedley, P.L. and Kinniburgh, D.G. (2013) Arsenic in Groundwater and the Environment. In: Selinus, O., Ed., Essential of Medical Geology, 279-210. http://dx.doi.org/10.1007/978-94-007-4375-5_12 
[31] Dill, H.G., Khadka, D.R., Khanal, R., Dohrmann, R., Melcher, F. and Busch, K. (2003) Infilling of the Younger Kathmandu-Banepa Intermontane Lake Basin During the Late Quaternary (Lesser Himalaya, Nepal): A Sedimentological Study. Journal of Quaternary Science, 18, 41-60. http://dx.doi.org/10.1002/jqs.726

[32] Gurung, J.K., Ishiga, H., Khadka, M.S. and Shrestha, N.R. (2007) The Geochemical Study of Fluvio-Lacustrine Aquifers in the Kathmandu Basin (Nepal) and the Implications for Mobilization of Arsenic. Environmental Geology, 52, 503-517. http://dx.doi.org/10.1007/s00254-006-0483-y

[33] WHO (2011) Guidelines for Drinking-Water Quality. 4th Edition, World Health Organization, Geneva.

[34] Pierce, M.L. and Moore, C.B. (1982) Adsorption of Arsenite and Arsenate on Amorphous Iron Hydroxide. Water Research, 16, 1247-1253. http://dx.doi.org/10.1016/0043-1354(82)90143-9

[35] McArthur, J.M., Ravenscroft, P., Safiulla, S. and Thirlwall, M.F. (2001) Arsenic in Groundwater: Testing Pollution Mechanisms for Sedimentary Aquifers in Bangladesh. Water Research, 37, 109-117. http://dx.doi.org/10.1029/2000WR900270

[36] Smedley, P.L. and Kinniburgh, D.G. (2002) A Review of the Source, Behavior and Distribution of Arsenic in Natural Waters. Applied Geochemistry, 17, 517-568. http://dx.doi.org/10.1016/S0883-2927(02)00018-5

[37] Anawar, H.M., Akai, J., Komaki, K., Terao, H., Yoshioka, T., Ishizuka, T., Safiullah, S. and Kato, K. (2003) Geochemical Occurrence of Arsenic in Groundwater of Bangladesh: Sources and Mobilization Processes. Journal of Geochemical Exploration, 77, 109-131. http://dx.doi.org/10.1016/S0375-6742(02)00273-X

[38] Bose, P. and Sharma, A. (2002) Role of Iron in Controlling Speciation and Mobilization of Arsenic in Subsurface Environment. Water Research, 36, 4916-4926. http://dx.doi.org/10.1016/S0043-1354(02)00203-8

[39] Biswas, A., Majumder, S., Neidhardt, H., Halder, D., Bhowmick, S., Mukherjee-Goswami, A., Kundu, A., Saha, D., Berner, Z. and Chatterjee, D. (2011) Groundwater Chemistry and Redox Processes: Depth Dependent Arsenic Release Mechanism. Applied Geochemistry, 26, 516-525. http://dx.doi.org/10.1016/j.apgeochem.2011.01.010

[40] Dzombak, D.A. and Morel, F.M.M. (1990) Surface Complexation Modeling: Hydrous Ferric Oxide, John Wiley \& Sons, New York.

[41] Helena, B., Pardo R., Vega, M., Barrado, E., Fernandez, J.M. and Fernandez, L. (2000) Temporal Evolution of Groundwater Composition in an Alluvial Aquifer (Pisuerga River, Spain) by Principal Component Analysis. Water Research, 34, 807-816. http://dx.doi.org/10.1016/S0043-1354(99)00225-0

[42] Daughney, C.J. (2003) Iron and Manganese in New Zealand's Groundwater. Journal of Hydrology (NZ), 42, 11-26.

[43] Fujii, R. and Sakai, H. (2001) Palynological Study on the Drilled Sediments from the Kathmandu Basin and Its Paleoclimatic Significances. Journal of Nepal Geological Society, 25, 53-61.

[44] Nickson, R.T., McArthur, J.M., Ravenscroft, P., Burgess, W.G. and Ahmed, K.M. (2000) Mechanism of Arsenic Release to Groundwater, Bangladesh and West Bengal. Applied Geochemistry, 15, 403-413. http://dx.doi.org/10.1016/S0883-2927(99)00086-4

[45] Akai, J., Izumi, K., Fukuhara, H., Masuda H., Nakano, S., Yoshimura, T. Ohfuji, H., Anawar, H. and Akai, K. (2004) Mineralogical and Geomicrobiological Investigations on Groundwater Arsenic Enrichment in Bangladesh. Applied Geochemistry, 19, 215-230. http://dx.doi.org/10.1016/j.apgeochem.2003.09.008

[46] Savarimuthu, X., Hira-Smith, M.M., Yuan, Y., von Ehrenstein, O.S., Das, S., Ghosh, N., Guha Mazumder, D.N. and Smith, A.H. (2006) Seasonal Variation of Arsenic Concentration in Tube Wells in West Bengal, India. Journal of Health Population and Nutrition, 24, 277-281.

[47] Sankar, M.S., Vega, M.A., Defoe, P.P., Kibria, M.G., Ford, S., Telfeyan, K., Neal, A., Mohajerin, T.J., Hettiarachchi, G.M., Barua, S., Hobson, C., Johannesson, K. and Datta, S. (2007) Elevated Arsenic and Manganese in Groundwaters of Murshidabad, West Bengal, India. Science of the Total Environment, 488-489, 570-579. http://dx.doi.org/10.1016/j.scitotenv.2014.02.077

[48] Chen, K., Jio, J.J., Huang, J. and Huang, R. (2007) Multivariate Statistical Evaluation of Trace Elements in Groundwater in a Coastal Area in Shenzhen, China. Environmental Pollution, 147, 771-780. http://dx.doi.org/10.1016/j.envpol.2006.09.002

[49] Cheng, Z., Vangeen, A., Seddique, A.A. and Ahmed, K.M. (2005) Limited Temporal Variability of Arsenic Concentrations in 20 Wells Monitored for 3 Years in Araihazar, Bangladesh. Environmental Science and Technology, 39, 4759-4766. http://dx.doi.org/10.1021/es048065f

[50] Thundiyil, J.G., Yuan, Y., Smith, A.H. and Steinmaus, C. (2007) Seasonal Variation of Arsenic Concentration in Wells in Nevada. Environmental Research, 104, 367-373. http://dx.doi.org/10.1016/j.envres.2007.02.007

[51] Filipek, L.H. and Owen, R.M. (1979) Geochemical Associations and Grain-Size Partitioning of Heavy Metals in Lacustrine Sediments. Chemical Geology, 26, 105-117. http://dx.doi.org/10.1016/0009-2541(79)90033-0

[52] Singh, A.K., Hasnain, S.I. and Banerjee, D.K. (1999) Grain Size and Geochemical Partitioning of Heavy Metals in Se- 
diments of the Damodar River-A Tributary of the Lower Ganga, India. Environmental Geology, 39, 90-98. http://dx.doi.org/10.1007/s002540050439

[53] Erickson, M.L. and Barnes, R.J. (2005) Well Characteristics Influencing Arsenic Concentrations in Groundwater. Water Research, 39, 4029-4039. http://dx.doi.org/10.1016/j.watres.2005.07.026

[54] Kouras, A., Katsoyiannis, I. and Voutsa, D. (2007) Distribution of Arsenic in Groundwater in the Area of Chalkidiki, Northern Greece. Journal of Hazardous Materials, 147, 890-899. http://dx.doi.org/10.1016/j.jhazmat.2007.01.124

[55] Smedley, P.L., Nicolli, H.B., MacDonald, D.M.J., Baros, A.J. and Tullio, J.O. (2002) Hydrogeochemistry of Arsenic and Other Inorganic Constituents in Groundwaters from La Pampa, Argentina. Applied Geochemistry, 17, 259-284. http://dx.doi.org/10.1016/S0883-2927(01)00082-8

[56] Carbonell-Barrachina, A.A., Jugsujinda, A., Burlo, F., Delaune, R.D. and Patrick, W.H. (1999) Arsenic Chemistry in Municipal Sewage as affected by Redox Potential and pH. Water Research, 34, 216-224. http://dx.doi.org/10.1016/S0043-1354(99)00127-X

[57] McArthur, J.M., Banerjee, D.M., Hudson-Edwards, K.A., Mishra, R., Purohit, R., Ravenscroft, P., Cronin, A., Howarth, R.J., Chatterjee, A., Talukder, T., Lowry D., Houghton, S. and Chada, D.K. (2004) Natural Organic Matter in Sedimentary Basins and Its Relation to Arsenic in Anoxic Groundwater: The Example of West Bengal and its Worldwide Implications. Applied Geochemistry, 19, 1255-1293. http://dx.doi.org/10.1016/j.apgeochem.2004.02.001

[58] Du Laing, G., Chapagain, S.K., Dewispelaere, M., Meers, E., Kazama, F., Tack, F.M.G., Rinklebe, J. and Verloo, M.G. (2009) Presence and Mobility of Arsenic in Estuarine Wetland Soils of the Scheldt Estuary (Belgium). Journal of Environmental Monitoring, 11, 873-881. http://dx.doi.org/10.1039/b815875d 